\title{
Retrospective evaluation of the effects of periprostatic local anesthesia on recurrent prostate biopsy
}

\author{
Periprostatik lokal anestezinin tekrarlayan prostat biyopsisi üzerine etkisinin \\ retrospektif olarak değerlendirilmesi
}

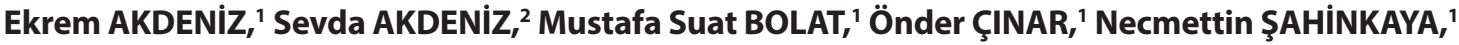 \\ Nevin Esra GÜMÜŞ²
}

\begin{abstract}
Summary
Objectives: The aim of the study was investigate the pain palliation effect of $2 \%$ dose of lidocaine on the periprostatic nerve block in prostate biopsy patients.

Methods: Extended (12 cores) and saturation ( 22 cores) biopsy patients were included. The patients were separated into three groups: extended biopsy patients (Group I), saturation biopsy patients (Group II), and control group patients undergoing a biopsy procedure for the first time (Group III). All patients received $2 \%$ lidocaine $(10 \mathrm{~mL})$ on both the seminal vesicular junction and apex of the prostate with transrectal ultrasonography guidance. Following the procedure, the pain levels of patients were assessed using a 10-cm linear Visual Analog Scale (VAS).

Results: Following the procedure, the VAS values of each group were $2.96 \pm 1.06,3.2 \pm 1.47$, and $2.93 \pm 0.94$, respectively $(p>0.05)$. While the highest pain score was seen in the saturation group patients (II), the lowest pain level was seen in the control biopsy group (III). However, no statistical di erence was observed among the groups.

Conclusion: Herein, we observed that a local injection using $2 \%$ lidocaine was effective as local anesthetic in recurrent prostate biopsies. In addition, it was found that the pain level increases as the number of cores taken in recurrent prostate biopsies increases; however, this has not been established statistically.
\end{abstract}

Keywords: Lidocaine; periprostatic local anesthesia; recurrent prostate biopsy.

\section{Özet}

Amaç: Çalışmamızda daha önce prostat biyopsisi deneyimi yaşayan ve yaşamayan hastalarda \%25 lidokain ile yapılan periprostatik sinir bloğunun ağrı palyasyonu açısından etkisi retrospektif olarak araştırılması amaçlanmıştır.

Gereç ve Yöntem: Çalışmamıza genişletilmiş (12 kor) ve satürasyon (22 kor) biyopsisi yapılan hastalar alındı. Hastalar, genişletilmiş biyopsi yapılan hastalar (Grup I), satürasyon biyopsisi yapılan hastalar (Grup II) ve ilk defa biyopsi yapılacak kontrol grubu hastalar (Grup III) olmak üzere 3 gruba ayrıldı. Tüm hastalara 10cc \%2 lidokain transrektal ultrasonografi (TRUSG) eşliğinde prostatın her iki seminal veziküler bileșkesine ve apeksine uygulandı. Isşlem sonrası hastaların ağrı düzeyleri $10 \mathrm{~cm}$ 'lik lineer Vizüel Analog Skala (VAS) aracılığıyla değerlendirildi.

Bulgular: İşlem sonrası grupların VAS değerleri sırasıyla $2.96 \pm 1.06,3.2 \pm 1.47$ ve $2.93 \pm 0.94$ olarak bulundu ( $p>0.05$ ). Sayısal olarak en yüksek ağrı skoru satürasyon grubu hastalarında bulunurken en düşük ağrı düzeyi genişletilmiş biyopsi yapılan grupta bulundu. Ancak gruplar arasında istatistiksel olarak bir fark izlenmedi.

Sonuç: Çalışmamızda \%2 lidokain kullanılarak yapılan periprostatik lokal anestezi enjeksiyonu tekrarlayan prostat biyopsilerinde etkili bir lokal anestezi sağladığı görülmüştür. Ayrıca tekrarlayan prostat biyopsilerinde alınan kor sayısı arttıkça ağrı düzeyinin arttığı bulunmuştur ancak bu durum istatistiksel olarak ortaya konulamamıştır.

Anahtar sözcükler: Lidokain, periprostatik lokal anestezi, pekrarlayan prostat biyopsisi.

'Department of Urology, Samsun Training and Research Hospital, Health Sciences University, Samsun, Turkey ${ }^{2}$ Department of Anesthesiology and Reanimation, Samsun Training and Research Hospital, Health Sciences University, Samsun, Turkey

Submitted (Başvuru tarihi) 18.07.2016 Accepted after revision (Düzeltme sonrası kabul tarihi) 30.09.2017 Available online date (Online yayımlanma tarihi) 08.11.2017

Correspondence: Dr. Ekrem Akdeniz. Sağlık Bilimleri Üniversitesi, Samsun Eğitim ve Araştırma Hastanesi, Üroloji Kliniği, Samsun, Turkey.

Phone: +90 - 362 - 3111500 e-mail: ekremakdeniz@yahoo.com

(c) 2017 Turkish Society of Algology 


\section{Introduction}

The standard method of diagnosis for prostate cancer is transrectal ultrasonography (TRUS) guided prostate needle biopsy. ${ }^{[1]}$ Pain arises from the puncture of the prostatic capsule with a needle and the stroma during the biopsy or the discomfort caused by the ultrasound probe in the rectum. ${ }^{[2,3]}$ Intrarectal lumbrical agents, periprostatic nerve block, intraprostatic anesthesia, pelvic nerve blocks, caudal block, pudendal nerve block, and general anesthesia can be administered for pain palliation prior to the procedure. ${ }^{[4]}$ The European Association of Urology suggests periprostatic nerve block for anesthesia in TRUS-guided prostate biopsies. ${ }^{\left[{ }^{[5]}\right.}$

Ten cores biopsy material are taken from the prostate of patients who receive a prostate biopsy for the first time. Indications for a re-biopsy are as follows: a biopsy was reported as an atypical small acinar proliferation (ASAP), high-grade prostatic intraepithelial neoplasia (HGPIN) in three or more previous biopsies, atypical glands along with the HGPIN or intraductal carcinoma in the previous biopsy rise in prostate-specific antigen (PSA) levels, and presence of a suspected digital rectal examination (DRE) finding or positive multiparametric magnetic resonance imaging finding ${ }^{[6-12]}$

Recurrent biopsies may be extended ( 12 cores) as a saturation biopsy (22 cores). The anesthesia method may not be effective because of increases in biopsy cores taken and longer procedure times. In such cases, different anesthesia may be required for recurring patients. This study investigates the effect in terms of pain palliation of the nerve block with $2 \%$ lidocaine in prostate biopsy patients.

\section{Materials and Methods}

The required Ethical Committee approval for our study was obtained from our Ethics Committee. Files of the patients who underwent a re-biopsy between January 2013 and June 2016 and whose informed surgical consent forms were obtained prior to the procedure were retrospectively examined. Overall, 90 patients were separated into three groups: extended biopsy ( 12 cores) patients (Group I, 30 patients), saturation biopsy (22 cores) patients (Group II, 30 patients), and the control group patients who underwent a biopsy for the first time (Group III, 30 patients). Saturation biopsy was performed on patients whose TRUS results were suspicious. The procedures were all performed by the same clinician. Follow-up period was 1 month to check for possible complications.

\section{Inclusion criteria}

- PSA values between 2.5 and $10 \mathrm{ng} / \mathrm{mL}$

- No rectal inspection findings prior to the first biopsy

- First biopsies with benign prostatic hyperplasia

- Patients whose prostate volumes are between 30 and $50 \mathrm{cc}$

- Patients younger than 75 years

\section{Exclusion criteria}

- Patients whose PSA values are more than $10 \mathrm{ng} /$ $\mathrm{mL}$ and whose DRE examinations are positive (because high-grade prostate cancer probability will increase and as the presence of a possible prostate cancer will affect the pain sensation due to periprostatic nerve invasion)

- Patients older than 75 years (because the neuropathic component of the pain will increase and as these patients cannot express their complaints)

- Patients who have received a prostatectomy earlier (because the pain sensation may be affected because inflammation or fibrosis may have become chronic following prostatectomy)

- Patients whose prostate volumes are below 30 $\mathrm{mL}$ or above $50 \mathrm{~mL}$ (because the size of prostate may affect the pain sensation)

- The first biopsy of those who were reported as ASAP and HGPIN (because of the possibility of cancer that has been missed in the first biopsy)

- Patients whose first biopsies were conducted at other centers

- Patients who describe pain in the pelvis area prior to the procedure (Chronic pelvic pain, chronic orchialgia, etc.)

- Patients who have recto-anal pathologies

- Patients using analgesics

\section{Procedure}

All patients were administered $500 \mathrm{mg}$ of ciprofloxacin twice the day prior to the procedure and for 4 days after, as described by Özden, et al. ${ }^{[13]}$ The patients were laid down in the left lateral decubitus position, and their knees and hips were at flexion. Prior to probe introduction, $60-\mathrm{mg}$ lidocaine gel was 
Table1. Demographic and clinic characteristics of the patients

\begin{tabular}{lcccc}
\hline & Group I & Group II & Group III & P \\
\hline $\mathrm{n}$ & 30 & 30 & 30 & \\
Age (years) & $57.26 \pm 4.9(49-73)$ & $60.93 \pm 7.1(49-74)$ & $56.5 \pm 5.69(49-74)$ & 0.261 \\
PSA (ng/ml) & $7.25 \pm 1.49(4.1-9.9)$ & $7.41 \pm 1.69(5.4-9.8)$ & $6.57 \pm 1.88(2.8-9.6)$ & 0.249 \\
PV (cc) & $37.76 \pm 9.05(23-50)$ & $39.83 \pm 8.35(28-50)$ & $39.66 \pm 7.58(25-50)$ & 0.231 \\
VAS (cm) & $2.96 \pm 1.06$ & $3.2 \pm 1.47$ & $2.93 \pm 0.94$ & 0.136 \\
\hline
\end{tabular}

PSA: Prostate-specific antigen; PV: Prostate volume; VAS: Visual Analog Scale.

applied intrarectally. Following a 7-10 minute waiting interval, a $6.5 \mathrm{MHz}$ rectal probe was introduced into the rectum. The prostate was viewed after introducing the probe, and the prostate volume was measured using the automatic ellipsoid program in the ultrasound device (height $\times$ width $\times$ length $\times 0.52$ ). Asymmetry or hypoechoic areas were identified. A total of $10 \mathrm{~mL} 2 \%$ lidocaine (Jetokain simplex ${ }^{\circledR}$ ampule, Adeka Pharmaceutical Company, Samsun, Turkey) was injected using a 7-inch 22-gauge spinal needle in the sagittal axis, i.e., $4 \mathrm{~mL}$ each at both prostate-seminal vesicle junction points and $2 \mathrm{~mL}$ at the prostate apex (Fig. 1). The syringe was aspirated prior to injection to prevent intravascular injection. A 25-cm 18-gauge biopsy needle and an automatic biopsy gun (Bard ${ }^{\oplus}$ Max-Core ${ }^{\circledR}$, Bard Peripheral Vascular Ins, 170 Tempe, USA) were used 5 minutes after the periprostatic injection to collect systematic 10-core, 12-core, and 22-core prostate biopsies. All patients were asked to describe their experiences during introduction of the ultrasound probe. They were asked to choose one of the following options: no-problem,

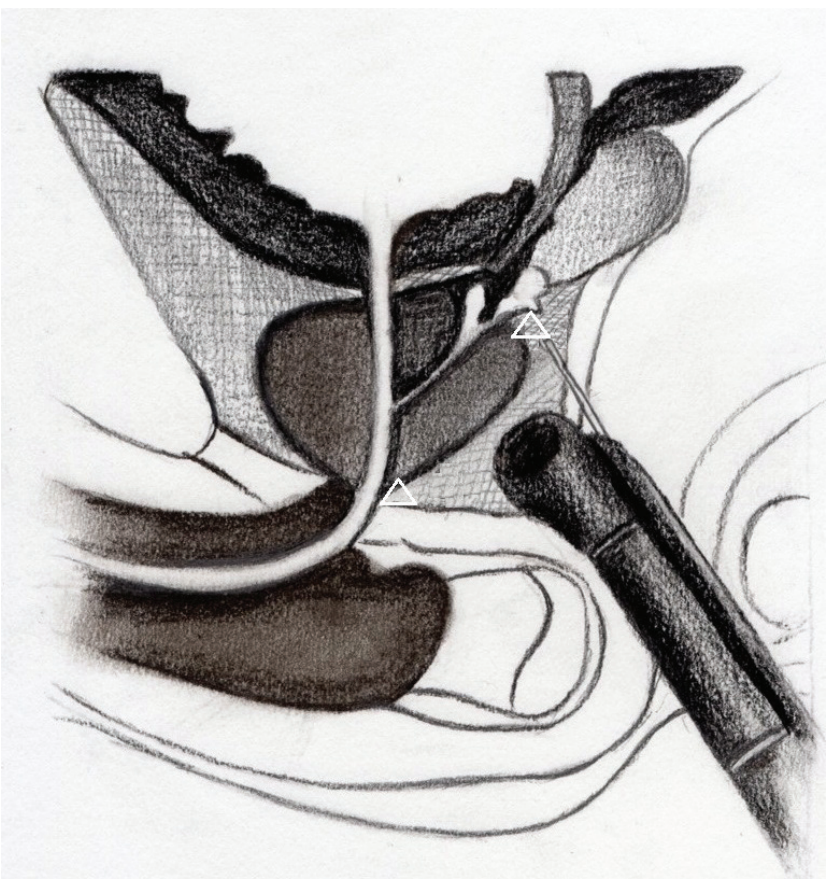

Figure 1. Injection points for local anaesthetic (Triangles). disturbing, painful, and very painful. Next, the patients' pain levels were identified using the 11-point linear Visual Analog Scale (VAS) $(0=$ no pain and $10=$ unbearable pain), as explained to them earlier, and the values were recorded. The pain was classified as follows: absence of pain, score of 0 ; mild pain, score of 0.1-3; moderate pain, score of 3.1-7; and severe pain, score of 7.1-10. ${ }^{[14]}$ All biopsies were performed as outpatient procedures. The VAS score values of the patients in the first two groups were compared with those in Group III.

\section{Statistical analysis}

The Statistical Package of Social Sciences 15 (SPSS 15.0, Chicago, IL, USA) program was used for statistical evaluation. The conformance of the data with the normal distribution was checked using the KolmogorovSmirnov test. The Kruskal-Wallis variance analysis was used for data analysis. Mann-Witney $U$ test was used for comparisons between the groups. All values were shown as the median \pm standard deviation (SD). The value of $p<0.05$ was accepted as meaningful.

\section{Results}

No differences were observed between the groups in terms of age, PSA value, and prostate volume (Table 1). When the patients were asked to describe their experience with the ultrasound probe introduction painful, none of the patients reported no-problem with probe introduction (Fig. 2). Moreover, 72 out of 90 patients

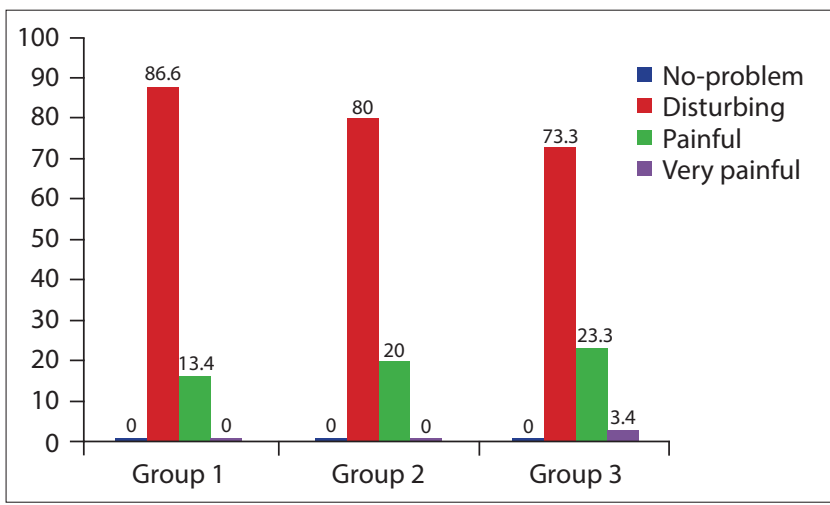

Figure 2. The pain level patients feel during probe introduction (\%). 
Table2. VAS score values in the first and second biopsies in the re-biopsy groups

\begin{tabular}{lccc}
\hline & First biopsy & Re-biopsy & p \\
\hline Group I & $2.6 \pm 1.10$ & $2.96 \pm 1.06$ & 0.938 \\
Group II & $2.73 \pm 1.28$ & $3.2 \pm 1.47$ & 0.151 \\
\hline
\end{tabular}

VAS: Visual analog scale.

(80\%) found the probe introduction disturbing. The number of patients in each group who found the probe introduction painful was four (4.4\%), six $(6.6 \%)$, and seven $(7.7 \%)$, respectively . Only one patient in Group III (1.1\%) showed that the probe introduction was very painful.

Following the procedure, the VAS values of the groups were found as $2.96 \pm 1.06,3.2 \pm 1.47$, and $2.93 \pm 0.94 \mathrm{~cm}$, respectively $(p>0.05)$. The highest pain score was found in Group II, and the lowest pain score in Group III. However, no statistical differences were observed between the groups. The number of the patients with moderate pain in all three groups were found to be 9 (30\%), 13 (43.4\%), and 8 (26.7\%), respectively. The largest number of patients reporting moderate levels of pain was in Group II. No patients reported suffering severe or mild pain (Fig. 3).

The VAS scores of patients in Group I and Group II following the first biopsies were $2.6 \pm 1.10$ and $2.73 \pm 1.28$ $\mathrm{cm}$, respectively (Table 2). No statistical difference was observed in these two groups' VAS scores from between the first biopsy and the re-biopsy. Furthermore, none of the patients found the re-biopsy procedure less painful compared to the first one.

Following the histopathological examinations of the biopsy parts, four patients were found to have prostate cancer in Group I, seven in Group II, and three in Group III.

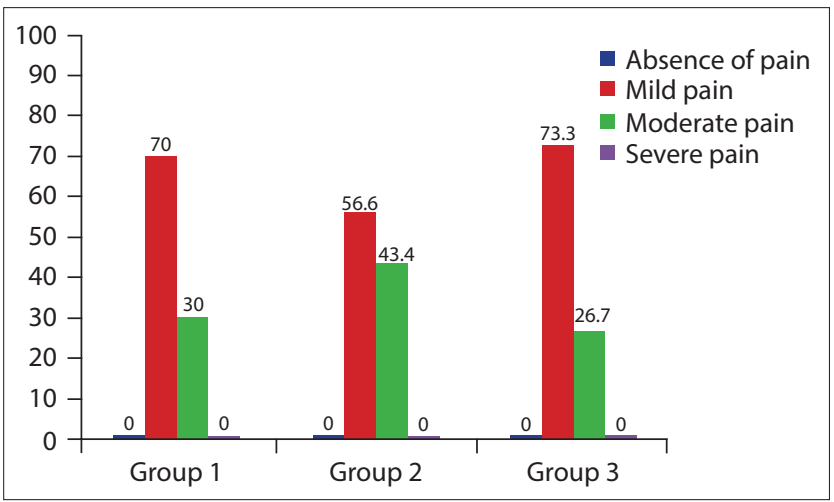

Figure 3. The pain level patients feel during the procedure (\%).

\section{Complications}

Two patients developed light hematuria, and two patients had a light rectal hemorrhage in Group I. Two patients developed light hematuria, three patients had light rectal hemorrhage, and one patient had hematospermia in Group II. Two patients developed light hematuria and one patient had a light rectal hemorrhage in Group III. Two patients in Group I and Group II complained of symptoms immediately after local anesthesia: one had lethargy and one had mild dizziness. All of these complications occurred in a self-restricting manner, and there was no need for intervention. One patient in Group II developed acute prostatitis, and 100.000 colonies of Escherichia Coli were found in the patient's urine culture. The patient was admitted to the hospital and was treated with ceftriaxone. The complication ratios in all three groups were at acceptable levels.

\section{Discussion}

Overall, 90 patients were admitted in our study. The low number is because the inclusion criteria were quite restrictive. Different factors contributed to reported pain. Strict inclusion criteria were employed to exclude, to the extent possible, the factors causing pain, and only the patients with higher PSA levels were admitted into the study. This led to a restriction in the number of patients.

All biopsies were performed by one surgeon. Re-biopsies had been planned first as extended 12-core biopsies, including the transitional zone. However, because of suspicious findings during TRUS, saturation biopsy was reverted, and a 22-core biopsy was performed. The number of focuses to be taken in re-biopsies is one of the most challenging issues faced by both the surgeon and the patient, and it is often unclear how many focuses will be needed. ${ }^{[15]}$ An ideal re-biopsy chart must be in compliance with clinical characteristics of the patient and should be considered for all patients whose first biopsies were received as ASAP or HGPIN. ${ }^{[16]}$ Because pathologies such as ASAP or HGPIN were excluded in our study, the saturation biopsy was performed on the basis of TRUS results only.

Seventy two of our patients (80\%) found the probe introduction disturbing. None of our patients indicated that introduction was problem-free. One patient in Group III reported very strong pain dur- 
ing introduction. The low number of patients in the study reporting strong pain during probe introduction stems from both the exclusion of patients with anorectal pathologies, such as anal fissures, fistulae, abscesses, hemorrhoids, and infections, and because intrarectal lidocaine gel was used prior to the procedure. Using the gel prior to starting reduces probe related frictions and protects the mucosa. In addition, lidocaine causes the smooth muscles in the anal canal to relax and reduces the anal sphincter tone. ${ }^{[4]}$ Because Group I and Group II patients had previous biopsy experiences, they may not have felt severe pain. However, no patient reported a problem-free probe introduction experience. While probe introduction in prostate biopsy may not be a very painful procedure, our study shows it is an annoying experience in terms of body position and methods used. When evaluating the pain experiences of biopsy patients as reported using the VAS scale, pain levels reported during both the probe insertion and the procedure itself were considered. During the biopsy procedure, the patients were observed as being confused about whether their pain was caused by probe introduction or by the biopsy stage. To prevent this confusion, pain due to probe insertion was evaluated using four categories: no pain, disturbing, painful, and very painful. Of the patients studied, 72 $(80 \%)$ reported that probe entry was disturbing and $18(20 \%)$ reported it as painful. The pain level upon probe introduction was reported as $1.95 \mathrm{~cm}$ by Tsuji, et al. and $1.56 \mathrm{~cm}$ by Tüfek, et al. ${ }^{[14,17]}$ In both studies, probe entry was found disturbing. Comparison of the present study with other studies may prove difficult because an evaluation of the use of VAS was not completed; however, the findings appear to be similar to other studies.

In our study, the VAS values in the three groups were found as $2.96 \pm 1.06,3.20 \pm 1.47$, and $2.93 \pm 0.94$ $\mathrm{cm}$, respectively. There is no statistical difference in the VAS scores between the groups. However, the group showing the highest number of pain is Group II. The higher pain level in Group II could be associated with the higher number of cores taken and the longer procedure time. Even though this cannot be established statistically, the pain level appears to increase commiserate with the increase in the number of cores taken. Moussa, et al. indicated that the pain levels in the patients who received re-biopsy were high, although it was not significant. ${ }^{[18]}$ Djavan, et al. demonstrated that there was no difference between the first procedure and the re-biopsies from a pain standpoint. ${ }^{[19]}$ In this aspect, the present study is in line with the literature.

Prostate biopsy is a painful procedure. Approximately $90 \%$ of the patients feel pain due to the procedure, and $5 \%$ state that the pain is unbearable. ${ }^{[18,20]}$ In all the groups, no patients reported no pain (VAS 0) or severe pain (VAS 7.1-10) (Fig. 3). The lowest pain level reported in all three groups was 1 in each group and the highest pain levels reported were 5,7 , and 6 , respectively. The number of patients who felt mild pain (VAS 0.1-3) in the groups was 21 (70\%), 17 (56.6\%), and 22 (73.3\%), respectively. Prostate biopsy is annoying in regards to the body position and methods used. The patients' experiences are reflected on their VAS scores. However, the average level of the VAS score across all three groups being 3 implies that the prostate biopsy procedure applied in the clinic studied is tolerable. The study has shown that the periprostatic local anesthesia performed with $2 \% \mathrm{li}$ docaine was a suitable method of pain palliation for both extended and saturation re-biopsies.

The first and the re-biopsy VAS values of the patients in Group I are $2.6 \pm 1.10$ and $2.8 \pm 1.18 \mathrm{~cm}$, respectively. There is no statistical difference between the first biopsy and the re-biopsy in terms of VAS. When the VAS values are compared on a patient-to-patient basis, the re-biopsy values of the six patients are higher than that of the first biopsy. In that group, the re-biopsy values of one patient are lower than that of the first biopsy. The first and re-biopsy VAS values of the Group II patients are $2.73 \pm 1.28$ and $3.2 \pm 1.47$ $\mathrm{cm}$, respectively. There is no statistical difference between the first biopsy and the re-biopsy. When the VAS values are numerically compared on a patientto-patient basis, the re-biopsy values of the $13 \mathrm{pa}$ tients are higher than that of first biopsy. Six patients in Group I and 13 patients in Group II found the rebiopsy more painful. None of the patients found the re-biopsy was less painful in Group II.

There are certain limitations in this study. First, it is not a randomized controlled study. In addition, the number of patients in each group is low. Independently, it is difficult to measure pain, and there is no standardized method for doing so. The pain that the individual feels may change on a daily basis. The pain 
scores used are subjective measures, and it is worth noting that they may vary based on the moods of the patients.

The positive aspects of our study include having the same surgeon performing the procedures while employing the same anesthesia method and the restrictive inclusion criteria eliminating the probable effects of pain.

\section{Conclusion}

The clinician's duties in prostate biopsies are to ensure that the patient suffers less pain with an effective anesthesia and that the procedure is more comfortable for the patient. The number of tissues taken in re-biopsies is high, and the procedure is longer. Even if not meaningful in this study, it was observed that the increase of severity of pain is commiserate to the increase in the number of cores taken. However, said it was also observed that periprostatic local anesthesia with $2 \%$ lidocaine is an effective method in pain palliation during prostate re-biopsies for the patient.

\section{Conflict-of-interest issues regarding the authorship or article: None declared.}

\section{Peer-rewiew: Externally peer-reviewed.}

\section{References}

1. Coley CM, Barry MJ, Fleming C, Wasson JH, Fahs MC, Oesterling JE. Should Medicare provide reimbursement for prostate-specific antigen testing for early detection of prostate cancer? Part II: Early detection strategies. Urology 1995;46(2):125-41. [CrossRef]

2. Nash PA, Bruce JE, Indudhara R, Shinohara K. Transrectal ultrasound guided prostatic nerve blockade eases systematic needle biopsy of the prostate. J Urol 1996;155(2):607-9.

3. Aus G, Hermansson CG, Hugosson J, Pedersen KV. Transrectal ultrasound examination of the prostate: complications and acceptance by patients. Br J Urol 1993;71(4):457-9.

4. Maccagnano C, Scattoni V, Roscigno M, Raber M, Angiolilli D, Montorsi F, et al. Anaesthesia in transrectal prostate biopsy: which is the most effective technique? Urol Int 2011;87(1):1-13. [CrossRef]

5. Heidenreich A, Bastian PJ, Bellmunt J, Bolla M, Joniau S, van der Kwast T, et al; European Association of Urology. EAU guidelines on prostate cancer. part 1: screening, diagnosis, and local treatment with curative intent-update 2013. Eur Urol 2014;65(1):124-37. [CrossRef]

6. Máderová E, Kestnerová V, Cervenka J, Puceková C. Preva- lence of nosocomial infections in selected hospitals. J Hyg Epidemiol Microbiol Immunol 1987;31(4):365-74.

7. Epstein Jl, Herawi M. Prostate needle biopsies containing prostatic intraepithelial neoplasia or atypical foci suspicious for carcinoma: implications for patient care. J Urol 2006;175(3 Pt 1):820-34. [CrossRef]

8. Shiraishi K, Oka S, Matsuyama H. Predictive Factors for Sperm Recovery after Varicocelectomy in Men with Nonobstructive Azoospermia. J Urol 2017;197(2):485-90.

9. Kronz JD, Shaikh AA, Epstein J. High-grade prostatic intraepithelial neoplasia with adjacent small atypical glands on prostate biopsy. Hum Pathol 2001;32(4):389-95. [CrossRef]

10. Guo CC, Epstein JI. Intraductal carcinoma of the prostate on needle biopsy: Histologic features and clinical significance. Mod Pathol 2006;19(12):1528-35. [CrossRef]

11. Donovan J, Hamdy F, Neal D, Peters T, Oliver S, Brindle L, et al; ProtecT Study Group. Prostate Testing for Cancer and Treatment (ProtecT) feasibility study. Health Technol Assess 2003;7(14):1-88. [CrossRef]

12. Walz J, Graefen M, Chun FK, Erbersdobler A, Haese A, Steuber $T$, et al. High incidence of prostate cancer detected by saturation biopsy after previous negative biopsy series. Eur Urol 2006;50(3):498-505. [CrossRef]

13. Ozden E, Bostanci Y, Yakupoglu KY, Akdeniz E, Yilmaz AF, Tulek $\mathrm{N}$, et al. Incidence of acute prostatitis caused by extended-spectrum beta-lactamase-producing Escherichia coli after transrectal prostate biopsy. Urology 2009;74(1):119-23.

14. Tsuji FH, Chambó RC, Agostinho AD, Trindade Filho JC, de Jesus CM. Sedoanalgesia with midazolam and fentanyl citrate controls probe pain during prostate biopsy by transrectal ultrasound. Korean J Urol 2014;55(2):106-11.

15. Capitanio U, Pfister D, Emberton M. Repeat Prostate Biopsy: Rationale, Indications, and Strategies. Eur Urol Focus 2015;1(2):127-36. [CrossRef]

16. Maccagnano C, Gallina A, Roscigno M, Raber M, Capitanio $U$, Saccà $A$, et al. Prostate saturation biopsy following a first negative biopsy: state of the art. Urol Int 2012;89(2):126-35.

17. Tüfek I, Akpinar H, Atuğ F, Öbek C, Esen HE, Keskin MS, et al. The impact of local anesthetic volume and concentration on pain during prostate biopsy: a prospective randomized trial. J Endourol 2012;26(2):174-7. [CrossRef]

18. Moussa AS, El-Shafei A, Diaz E, Gao T, Zaytoun OM, Fareed $\mathrm{K}$, et al. Identification of the variables associated with pain during transrectal ultrasonography-guided prostate biopsy in the era of periprostatic nerve block: the role of transrectal probe configuration. BJU Int 2013;111(8):1281-6. [CrossRef]

19. Djavan B, Waldert M, Zlotta A, Dobronski P, Seitz C, Remzi $M$, et al. Safety and morbidity of first and repeat transrectal ultrasound guided prostate needle biopsies: results of a prospective European prostate cancer detection study. J Urol 2001;166(3):856-60. [CrossRef]

20. Zisman A, Leibovici D, Kleinmann J, Siegel YI, Lindner A. The impact of prostate biopsy on patient well-being: a prospective study of pain, anxiety and erectile dysfunction. J Urol 2001;165(2):445-54. [CrossRef] 